\title{
Impact of torrefaction technique on the moisture contents, bulk density and calorific value of briquetted biomass
}

\author{
M. Azam Saeed ${ }^{1}$, Syed Waqas Ahmad ${ }^{1 *}$, Mohsin Kazmi², Muhammad Mohsin ${ }^{1}$, Nadeem Feroze \\ ${ }^{1}$ University of Engineering and Technology (Lahore) Faisalabad Campus, Faisalabad, Pakistan, 38000 \\ ${ }^{2}$ University of Engineering \& Technology, Department of Chemical Engineering, Lahore, Pakistan, 54890 \\ "Corresponding author: e-mail: Syed.waqas.ahmad@gmail.com
}

\begin{abstract}
The concept of different compositional biomass is introduced to enhance the binding properties and utilize the use of different seasonal biomasses. The effect of densification on the heating values of single pure and mixed compositional biomasses is observed with and without applying special type of pretreatment named as 'Torrefaction'. The moisture contents and bulk densities were also calculated for these briquettes. The effects of average moisture contents and bulk density (which show the swelling nature) on the heating values are also observed. The experiments have been performed on the pelletizer equipment to form briquetted biomass and bomb calorimeter was used to determine the calorific values of different briquettes. Finally, the percentage decrease in the average moisture contents of different categories of torrefied briquettes from non-torrefied briquettes were also calculated and compared.
\end{abstract}

Keywords: torrefaction, briquette, biomass, moisture contents, calorific value.

\section{INTRODUCTION}

The depletion of fossil fuel reserves (especially sweet crude oil) is the major issue in the energy sectors. Researchers are trying to explore environmental friendly and renewable energy resources. In these circumstances, agricultural biomass becomes crucial energy source in the country like Pakistan, where $90 \%$ of agricultural biomass is wasted.

Researchers have been trying to develop different techniques to modify the biomass properties since last decade. Among these techniques, torrefaction draws more attention because it can alter the physical properties of the fuel. According to ${ }^{1,2}$ torrefaction was the process that involves in the preheating of biomass under inert environmental conditions up to $573 \mathrm{~K}$. Recently, Chou et al. $^{3}$ tried to develop compact and densified solid biomass derived from rice straw; while rice bean was used as a binder. They first crushed the raw material (rice straw) into small sizes ranging from $10 \mathrm{~mm}$ to less than $2 \mathrm{~mm}$ using a home-made crusher. Briquetting was achieved by compressing crushed rice straw and rice bran in different proportions using piston-mold system. They reported that the heating value of the compressed mass increases as the fraction of rice bran increases. Furthermore, Arias et al. ${ }^{4}$ experimentally observed that the moisture contents of the wood based biomass (i.e. eucalyptus) reduced significantly by the application of torrefaction technique.

Phanphanich and $\mathrm{Mani}^{5}$ moved a step further from it and employed torrefaction technique on forest based biomass (including wood chips and forest residues). They further analyzed the fuel characteristics in relation with torrefaction. The raw material was torrefied in the presence of nitrogen to avoid combustion. After torrefaction, crushing was performed heavy duty knife mill. The results of torrefied biomass were compared with non-torrefied biomass. It was reported by the authors $^{5}$, that the value of energy consumption of grinding mill decreased by 10 times for torrefied biomass as compared to untreated material. Furthermore, the heating value was also found to be augmented due to torrefaction. Similar observation were reported by ${ }^{4,6,7}$ that the power consumption required for grinding the biomass reduced significantly due to the application of torrefaction technique.

Felfli et al. $^{8}$ performed several experiments by employing torrefaction technique using wood briquette. They found that the torrefied briquette contains $15 \%$ more heating value and $73 \%$ less moisture contents as compared to non-torrefied briquette. Further, the torrefaction process makes the briquette hydrophobic and it can be feasible to store in a humid environment. Moreover, Wamukonya and Jenkins ${ }^{9}$ studied the effect of briquetting process on different biomass (i.e. sawdust, wheat straw of Kenyan origin). They reported that the storage of briquetted biomass is more durable in a humid environment in comparison with non- briquetted biomass. Further, Li et al. ${ }^{10}$ studied the effect of compression pressure for producing densified briquette when examined municipal solid waste as raw fuel. They reported that with the application of $100 \mathrm{MPa}$ compact pressure, the moisture contents of the fuel reduced to $15 \%$.

Another drawback of using biomass as a fuel is associated to its low density. This problem increases the cost which is involved in storing, transportation and utilization of biomass. It is suggested that this financial loss due low density of the biomass can be minimized by increasing its density by using pellet mill, extrusion or briquetting techniques ${ }^{11}$. Islam et al. ${ }^{12}$ applied briquetting technique on different proportion of seasonal biomasses (i.e. rice husks, rice straw, bagasse and sawdust) using screw press. They reported that the utilization and storage of the briquetted biomass was economically more feasible as compare to un-briquetted biomass. Earlier, Werther et al. ${ }^{13}$ reviewed the work on the biomass and suggested that the densification results in more effective and efficient combustion. Kaliyan and Morey ${ }^{14}$ reviewed the importance of densification in biomass fuel. They also suggested that densification processes can make the handling of biomass easy.

It can be summarized that different techniques are required to employ the effective and efficient use of the 
biomass. In the present studies three biomasses namely; bagasse, rice husk and wheat straw (both in pure and different compositional form) were examined under torrefied and non-torrefied condition. The torrefaction temperature was varied as $200^{\circ} \mathrm{C}, 250^{\circ} \mathrm{C}$ and $300^{\circ} \mathrm{C}$. The physical properties like moisture contents, calorific value and bulk density was also determined.

\section{MATERIAL AND METHODS}

\section{Raw material}

During the present studies, three different kind of seasonal biomasses were used; namely rice husk, bagasse and wheat straw. In first set of experiments pure raw material were used, while in second set different compositions were employed for experiment, see in Table 1.

The average mass of the sample was 80 grams, while 120 grams amount of starch as a binder was mixed in every sample of biomass.

\section{Processing of raw samples}

Rice husk, bagasse and wheat straw were first crushed separately using double roll crusher and then sieved for half an hour to get the average particles size of $2.275 \mathrm{~mm}$. Then the samples were mixed in different compositions as discussed in Table 1 and then soaked into the tap water for 4 hours. These samples were dried at $104^{\circ} \mathrm{C}$ for half an hour in a Memmert oven (Model no. 300). After drying, each sample was soaked with dilute hydrochloric acid $(10 \%)$ for 24 hours in order to neutralize the base impurities and then rewashed with distilled water and dried again in the oven at $104^{\circ} \mathrm{C}$ for two hours.

Table 1. Composition of the biomass samples at different torrefaction temperatures

\begin{tabular}{|c|c|c|c|c|}
\hline \multirow[t]{2}{*}{ Sample No. } & \multicolumn{3}{|c|}{ Composition by mass } & \multirow[t]{2}{*}{$\begin{array}{c}\text { Torrefaction } \\
\text { Temperature }\end{array}$} \\
\hline & $\begin{array}{l}\text { Rice husk } \\
\text { (RH) }\end{array}$ & $\begin{array}{l}\text { Bagasse } \\
\text { (B) }\end{array}$ & $\begin{array}{c}\text { Wheat } \\
\text { straw (WS) }\end{array}$ & \\
\hline 1 & $100 \%$ & 0 & 0 & \multirow{12}{*}{$200^{\circ} \mathrm{C}$} \\
\hline 2 & 0 & $100 \%$ & 0 & \\
\hline 3 & 0 & 0 & $100 \%$ & \\
\hline 4 & $75 \%$ & $25 \%$ & 0 & \\
\hline 5 & $50 \%$ & $50 \%$ & 0 & \\
\hline 6 & $25 \%$ & $75 \%$ & 0 & \\
\hline 7 & 0 & $25 \%$ & $75 \%$ & \\
\hline 8 & 0 & $50 \%$ & $50 \%$ & \\
\hline 9 & 0 & $75 \%$ & $25 \%$ & \\
\hline 10 & $25 \%$ & 0 & $75 \%$ & \\
\hline 11 & $50 \%$ & 0 & $50 \%$ & \\
\hline 12 & $75 \%$ & 0 & $25 \%$ & \\
\hline
\end{tabular}

*The experiments were repeated for $250^{\circ} \mathrm{C}, 300^{\circ} \mathrm{C}$ (torrefaction temperature) and without torrefaction

\section{Torrefaction process}

For torrefaction all samples were classified into four sets and torrefaction was performed at three different temperatures, i.e. $200^{\circ} \mathrm{C}, 250^{\circ} \mathrm{C}$ and $300^{\circ} \mathrm{C}$, see Table 1 . While the fourth set of the samples was kept non-torrefied for comparison. The torrefaction process was performed using vacuum oven drier for 20 minutes in the absence of air.

\section{Briquetting process}

After torrefaction, the each sample was mixed with fixed amount of binder (120 grams of starch) and then was briquetted, of fixed diameter approximately 4 ", by placing it in hydraulic compression machine, which was a plunger type thermal dewatering unit. The compression machine was operated at $2800 \mathrm{psig}$ and $80^{\circ} \mathrm{C}$, see Table 2 for further specification. Similar procedure was repeated for non-torrefied samples.

\section{Analysis}

Moisture contents, bulk density and calorific value were determined for all samples of torrefied and non-torrefied biomasses.

\section{Moisture Contents}

The different samples of non-torrefied and torrefied biomasses were, first, kept in oven for 2 hours and then weighed. After that the same procedure was repeated for 2 hours and weight of the samples was measured again. This process was observed until the weight of the samples become constant. For calculation, the total mass loss of the each sample and percentage moisture content was calculated using equations (1) and (2).

Total weight lost $=$ initial mass of the sample - final mass of the sample

Percentage moisture contents $=\frac{\text { Total weight lost in the oven }}{\text { Intinal mass of the sample }} \times 100$

Same procedure was repeated for the samples which were torrefied at different conditions of temperature.

\section{Bulk Density}

After the briquetting, the regular cylindrical shaped briquettes were weighed on the weight balance and the height of these regular shaped briquettes for different samples was measured having fixed diameters of 4 ". The volume of the briquettes was calculated using equation (3).

$\mathrm{V}=\frac{\pi}{4} \mathrm{D}^{2} \mathrm{H}$

Where $\mathrm{V}=$ volume of the sample

$\mathrm{D}=$ diameter of the briquetted sample

$\mathrm{H}=$ height of the briquetted sample

The density of the sample was calculated using equation (4).

$\rho=\frac{M}{V}$

Where $\mathrm{M}=$ mass of the sample

$\varrho=$ density of the sample

\section{Calorific Values}

The calorific values of each briquette (both torrefied and non-torrefied) were measured using bomb calorimeter. The small weighted sample was placed in the crucible. The crucible was then placed over a ring while a fine Magnesium wire touching the sample which was used for producing a spark. The lid was tightly screwed and bomb was filled with $\mathrm{O}_{2}$ up to a pressure of approximately 25 atm (guage). The crucible was, then, placed in the bomb calorimeter. After the initial $10 \mathrm{~min}$, the fire time started and sample would be combusted in the next $10 \mathrm{~min}$. The bomb calorimeter was connected to a personal computer, which showed the calculated calorific value using software. 


\section{RESULTS AND DISCUSSION}

In the proceeding section, moisture contents, bulk density and calorific values of torrefied and non-torrefied biomasses were graphically represented and discussed.

\section{Effect of torrefaction on moisture contents}

The moisture contents for pure torrefied and nontorrefied biomasses were represented in this section. Figure 1 represents the percentage moisture contents at different torrefaction temperatures for three different biomass, i.e. bagasse, rice husk and wheat straw. The results then compared with non-torrefied biomasses of respective materials. It can be observed that the percentage moisture contents of non-torrefied biomass is maximum and then it decreases sharply when the respective biomass was torrefied at $200^{\circ} \mathrm{C}$. As the torrefaction temperature increases the reduction in the moisture contents was at sluggish rate, see Figure 1. Further, the rate of the reduction of the moisture contents in case of rice husk was found to be maximum as compared to the bagasse and wheat straw. It can also be noted that the nature of material was important, i.e. the initial moisture contents of rice husk was comparatively high as compare to rest of the chosen biomasses, see equation (5).

$(M C)_{i, R H}>(M C)_{i, W S}>(M C)_{i, B}$

Whereas, Figure 2 shows the impact of torrefaction temperature on percentage moisture contents of various combination of biomasses. Similar to pure biomasses, it

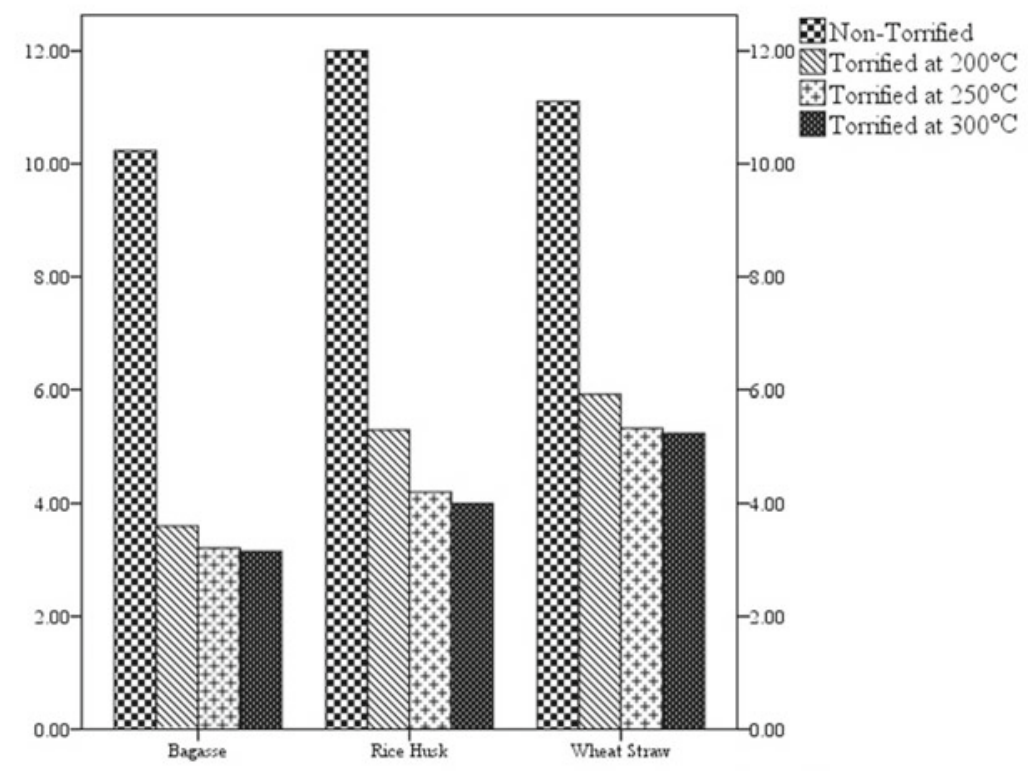

Figure 1. Percentage moisture contents of pure torrefied and non-torrefied biomasses

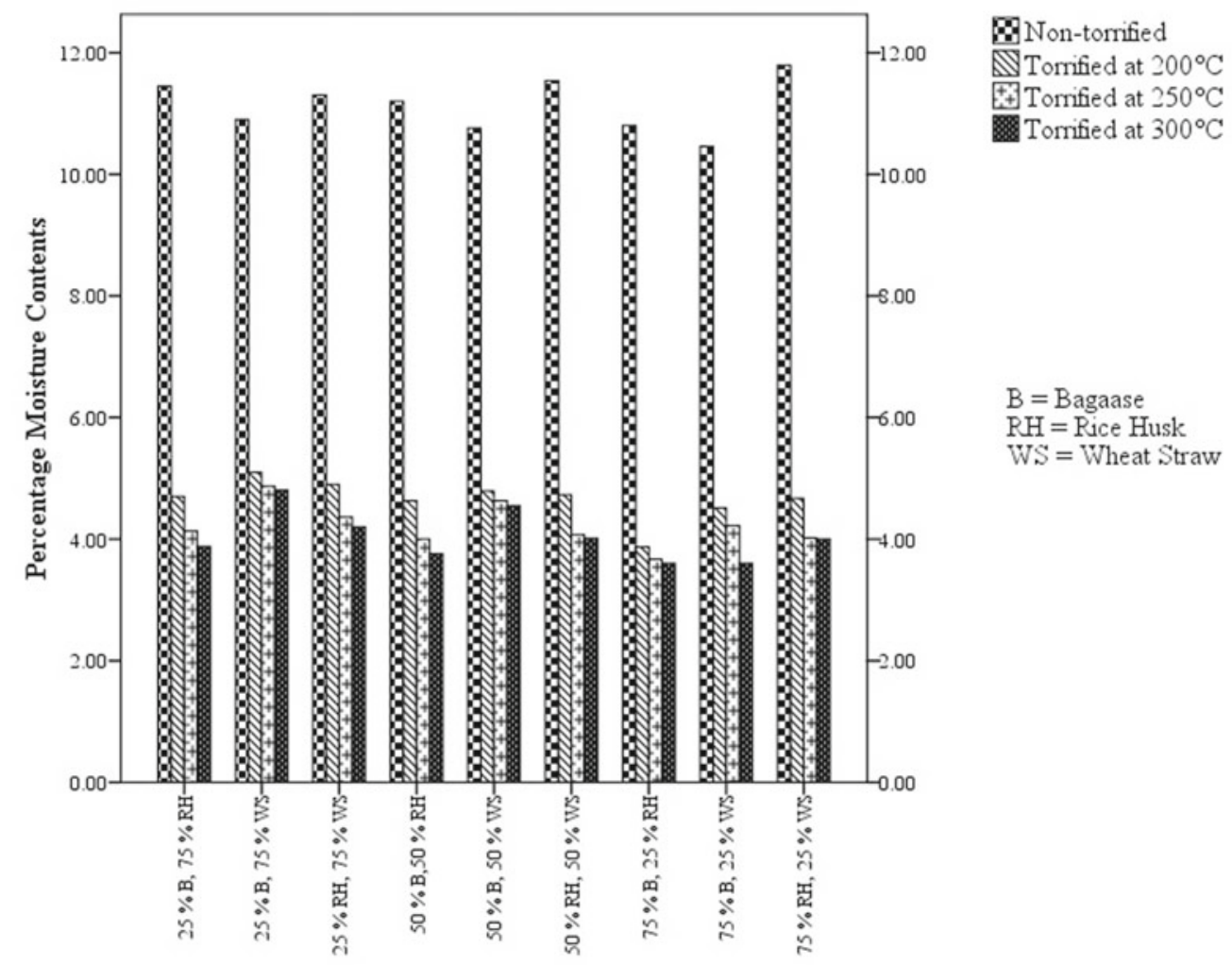

Figure 2. Percentage moisture contents of different compositional torrefied and non-torrefied biomasses 
can be noted, in case of mixed biomass, that the percentage moisture contents was decreased at sharp rate when torrefied at $200^{\circ} \mathrm{C}$ when the results were compared with non-torrefied conditions. The rate of reduction in percentage moisture contents was found to be decreased as the torrefaction temperature was raised. As discussed earlier that the initial moisture content of rice husk was high. In case of mixed biomass, it can be observed that the sample which has high composition of rice husk contents high initial moisture contents.

The initial moisture content of the biomasses depends on the nature of the material and location of the source. The high moisture contents of rice husk were due to its high water absorbing nature, similar observations regarding moisture contents were reported by Islam et al. ${ }^{\mathbf{1 2}}$.

The sharp decrease in the percentage moisture contents when the torrefied biomass was compared to non-torrefied biomass was due to the removal of free moisture which was reside with the material. With the increase in the torrefaction temperature, the chemically bonded moisture also removes with free moisture contents. The torrefaction results in the breakdown of hemicellulose network, which is due to the opening of active lignin sites on the surface results in the removal of chemically bonded moisture contents ${ }^{6}$. It can also change the chemical structure of the material. Furthermore, the rate of the removal of chemical bonded moisture increases with rise in torrefaction temperature.

\section{Effect of torrefaction on the bulk density}

In the preceding section, the impact of torrefaction on the bulk density of the pure and mixed proportions biomasses is being discussed. In Figure 3, it can be noted that the bulk density of bagasse is comparatively high than other respective biomasses, i.e. rice husk and wheat straw. Moreover, the torrefaction results in the augmentation of the bulk densities. Similar trends can be observed in case of mixed biomasses, i.e. the torrefied biomass has high bulk density, see Figure 4.

The high value of the bulk density of non-torrefied bagasse is due to the high lignin contents which, act as a binder, tightly pack the biomasses ${ }^{15}$. In case of tor-

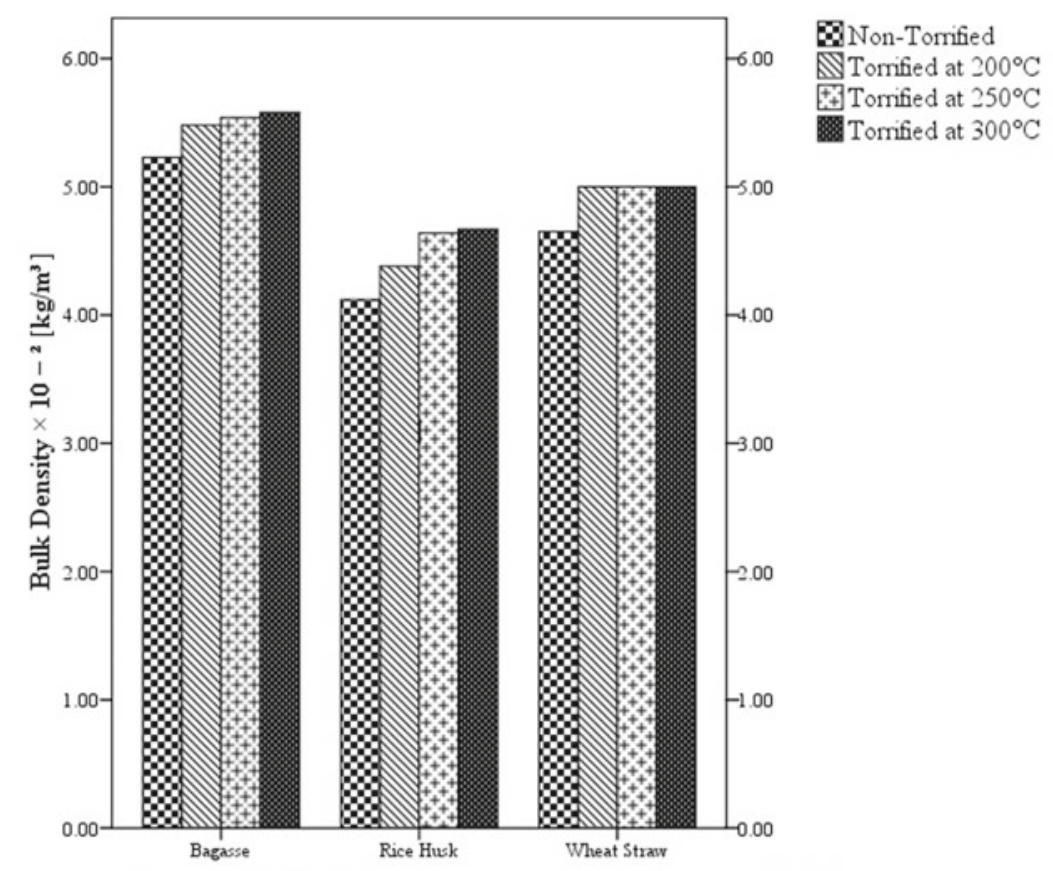

Figure 3. Bulk density for the pure torrefied and non- torrefied biomasses

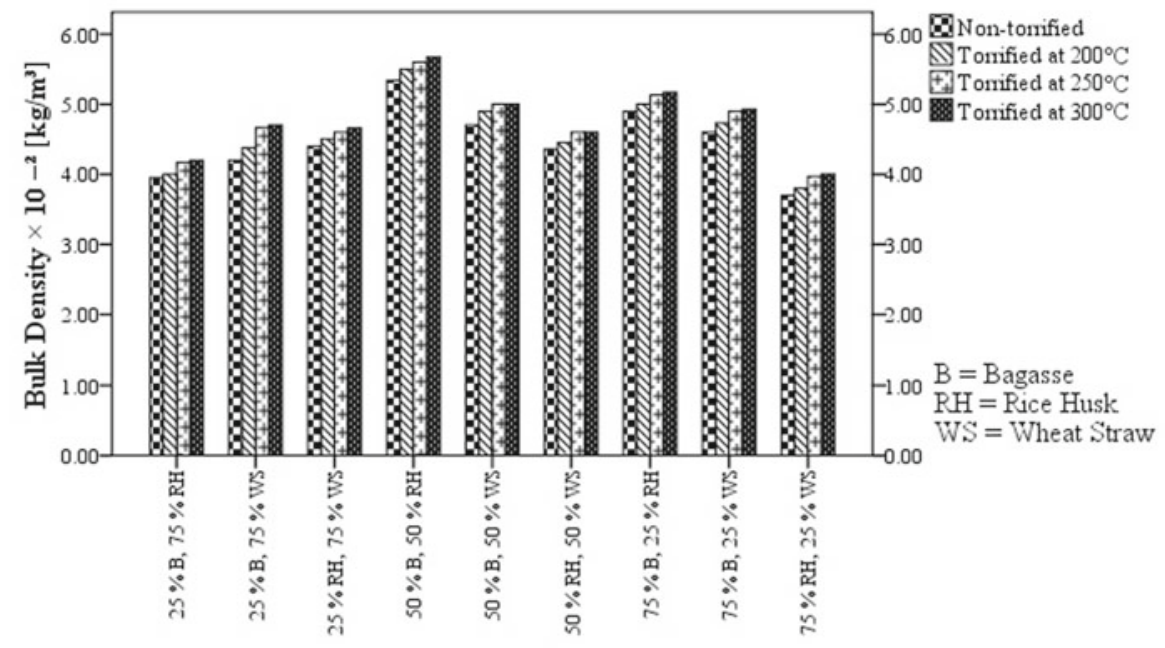

Figure 4. Bulk density for different compositional torrefied and non torrefied biomasses 
refaction, as discussed earlier, the lignin sights become active which leads to increase in the lignin contents within the biomass. This increment in the lignin contents improves the binding ability of the biomasses and consequently enhances the bulk densities of the biomasses which was also reported by Gravalos et al. ${ }^{\mathbf{1 6}}$. Similarly, for different compositional non-torrefied biomass, the briquettes compose of high lignin contents are more compact and results in high bulk densities. For torrefied biomasses, the porosities and moisture reduction results in the enhancement of the bulk densities of the different proportions biomasses ${ }^{12}$.

\section{Effect of torrefaction on the calorific values}

The calorific values of different pure biomasses are being compared for terrified and non-torrefied conditions see in the Figure 5. It can be seen that the calorific value of bagasse is high as compared to the other respective biomasses. Further, the rise in the calorific value can be seen for all pure biomasses at different torrefaction conditions when compared with non-terrified pure biomasses. It can be observed that the calorific values were increased sharply from torrefied to non-torrefied biomass at $200^{\circ} \mathrm{C}$ (torrefaction temperature), while the increment in torrefaction temperature resulted in sluggish increase in calorific value see Figure 5. Same trend is observed for different compositional biomasses, see Figure 6.

The high calorific value of bagasse may be due to its chemical nature, i.e. high lignin contents and inefficient burning ability ${ }^{17}$. The declination of the moisture contents due to the increment of the torrefaction temperature and reduction in the porosities in the biomasses in tight packing, results in the increase in the calorific values of pure and different compositional biomasses as experienced by Jenkins et al. ${ }^{\mathbf{}}$.

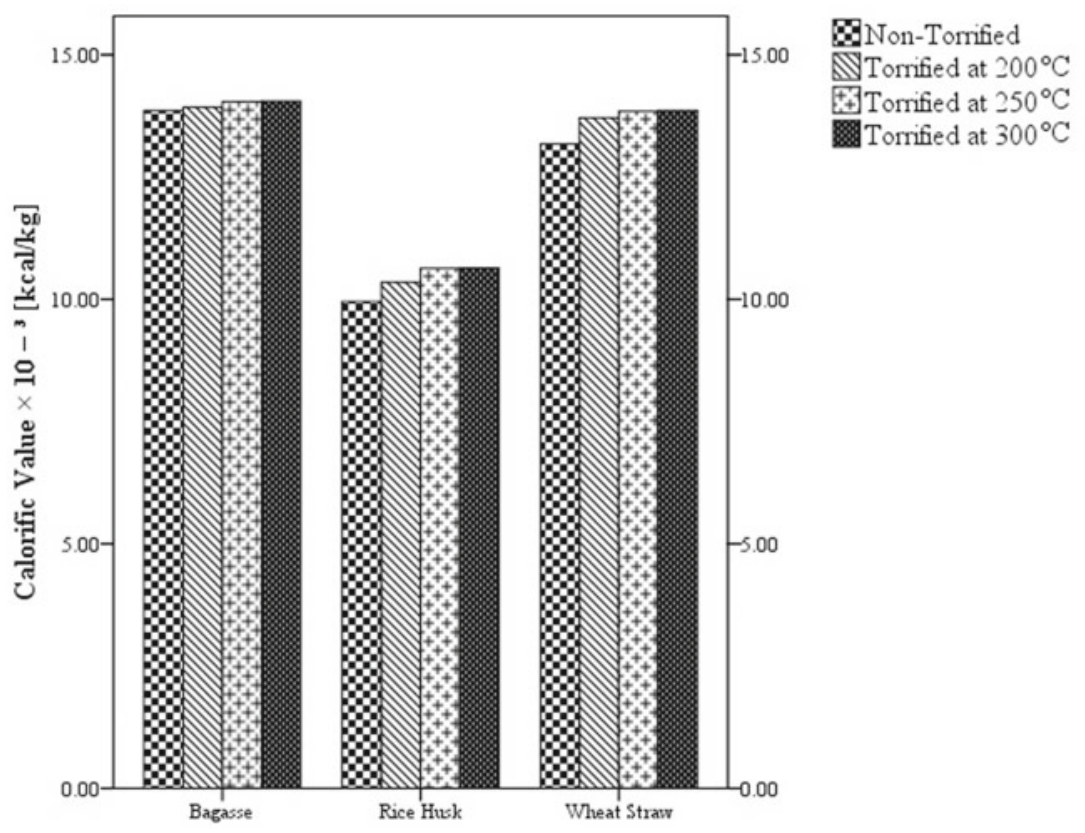

Figure 5. .Calorific Values of different pure torrefied and non-torrefied biomasses

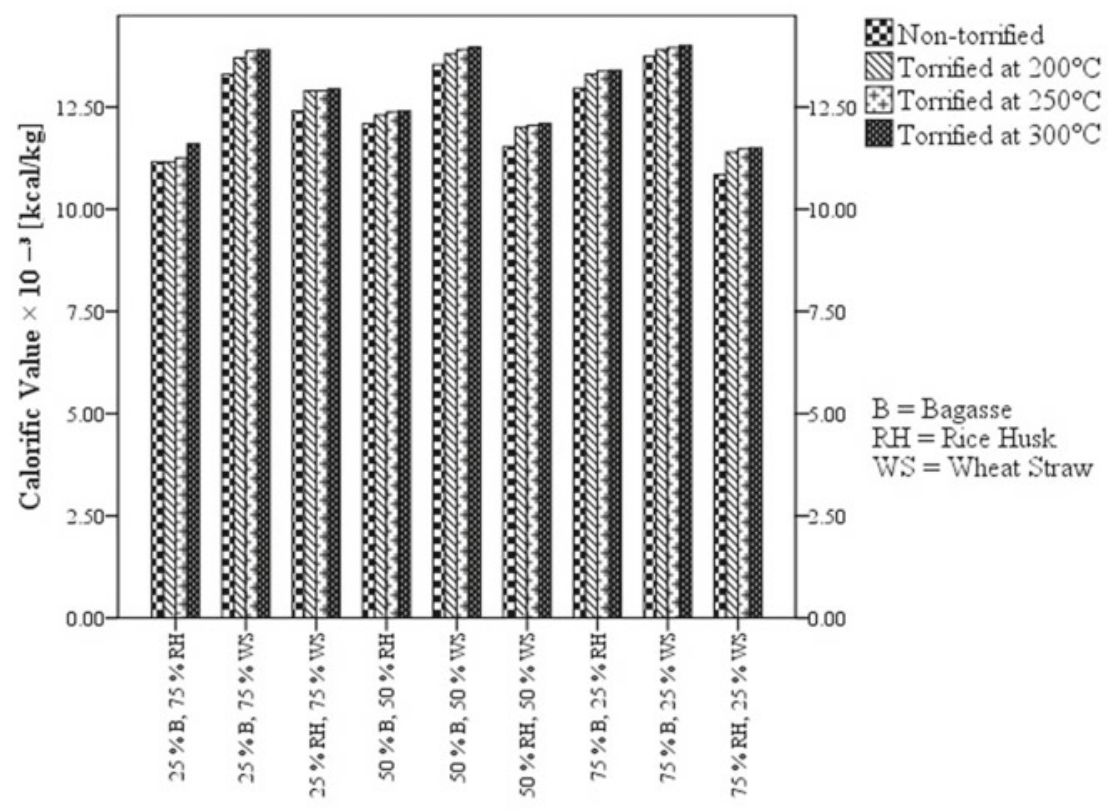

Figure 6. .Calorific Values of different compositional torrefied and non-torrefied biomasses 


\section{CONCLUSION}

In this study, the effect of torrefaction temperature on the bagasse, wheat straw and rice husk (both in pure and different proportions) was experimentally examined. The physical properties like moisture contents, bulk density and calorific value were measured and compared for both torrefied and non- torrefied biomasses.

It can be concluded that:

1. The moisture contents, calorific value and bulk density of non-torrefied pure and mixed compositional biomasses depends upon the nature of the biomass and its source.

2. Torrefaction results sharp decrease in the moisture contents due the removal of free moisture, which is associated with non-torrefied biomass. Moreover, the increment in torrefaction temperature results in depletion of chemically bonded moisture.

3. Torrefaction technique results in the augmentation of bulk density and calorific value due to the decrease in the moisture content and increase in the lignin content within the biomass.

It is suggested that the present studies should be further extended to measure the proximate analysis to observe the chemical nature of the terrified biomass and compared the results with non-torrefied biomass.

\section{ACKNOWLEDGEMENT}

Technical and Financial support of University of Engineering \& Technology Lahore Pakistan is highly appreciated.

\section{NOMENCLATURE}

V - Volume of the sample $\left[\mathrm{m}^{3}\right]$

D - Diameter of the briquetted sample [M]

$\mathrm{H} \quad-$ Height of the briquetted sample [M]

M - Mass of the sample $[\mathrm{Kg}]$

\section{Greek symbol}

P - Density of the sample $\left[\mathrm{kg} / \mathrm{m}^{3}\right]$

\section{Abbreviations}

$\begin{array}{ll}\text { Bagasse } & - \text { B } \\ \text { Rice husk } & - \text { RH } \\ \text { Wheat Straw } & - \text { WS }\end{array}$

Moisture contents - MC

\section{Subscript}

i $\quad-$ Initial

\section{LITERATURE CITED}

1. Ciolokosz, D. \& Wallace, R. (2011). A review of torrefaction for bioenergy feed stock product. Biofuels, Bioprod. Biorefin. 5(3), 317-329. DOI: 10.1002/bbb.275.

2. Medic, D., Darr, M., Shah, A., Potter, B. \& Zimmerman, J. (2012). Effect of torrefaction process parameters on biomass feedstock upgrading. Fuel 91(1), 147-154. DOI: 10.1016/j. fuel.2011.07.019.

3. Chou, C.S., Lin, S.H., \& Lu, W.C. (2009). Preperation and characterization of solid biomass fuel from rice straw and rice bran. Fuel Process. Technol. 90(7-8), 980-987. DOI: 10.1016/j. fuproc.2009.04.012.
4. Arias, B., Pevida, C., Fermoso, J., Plaza, M.G., Rubiera, F. \& Pis, J.J. (2008). Influence of torrefaction on the grindability and reactivity of woody biomass. Fuel Process. Technol. 89(2), 169-175. DOI: 10.1016/j.fuproc.2007.09.002.

5. Phanphanich, M. \& Mani, S. (2011). Impact of torrefaction on the gridability and fuel characteristics of forest biomass. Bioresour. Technol. 102(2), 1246-1253. DOI: 10.1016/j. biortech.2010.08.028.

6. Bergman, P.C.A. \& Kiel, J.H.A. (2005). Torrefaction for biomass upgrading. In 14th European Biomass Conference, Paris, France.

7. Hakkou, M., Petrissans, M., Gerardin, P. \& Zoulalian, A. (2006). Investigations of the reasons for fungal durability of heat-treated beach wood. Polym. Degrad. Stab. 91(2), 393-397. DOI: 10.1016/j.polymdegradstab.2005.04.042.

8. Felfli, F.F., Luengo, C.A., Suarez, J.A. \& Beaton, P.A. (2005). Wood briquette torrefaction. Energy Sustainable Dev. 9(3), 19-23. DOI: 10.1016/S0973-0826(08)60519-0.

9. Wamukonya, L. \& Jenkins, B. (1995). Durability and relaxation of sawdust and wheat-straw briquettes as possible fuel for Kenya. Biomass Bioenergy 8(3), 175-179. DOI: 10.1016/0961-9534(95)00016-Z.

10. Li, Y., Liu, H. \& Zhang, O. (2001). High pressure compaction of municipal solid waste to form densified fuel Fuel Process. Technol. 74(2), 81-91. DOI: 10.1016/S0378-3820(01)00218-1.

11. Tumuluru, J.S., Wright, C.T., Kenney, K.L. \& Hess, J.R. (2010). A technical review on biomass processing: densification, preprocessing, modeling and optimization. In Proceeding of ASABE Annual International Meeting, Pittsburgh, Pennsylvania.

12. Islam, M.M., Khan, K., Ali, M.N. \& Islam, M.S. (2003). An investigation on the raw materials and products of the briquetting machine. In Synopsis on The Role of Renewable and Alternative Energy Resources for National Development.

13. Werther, J., Salnger, M., Hartge, E.U., Ogada, T. \& Siagi, Z. (2000). Combustion of agriculture residues. Prog. Energy Combust. Sci. 26(1), 1-27. DOI: 10.1016/S0360-1285(99)00005-2.

14. Kaliyan, N. \& Morey, R.V. (2009). Review: Factors affecting strength and durability of densified biomass products. Biomass Bioenergy 33(3), 337-359. DOI: 10.1016/j. biombioe.2008.08.005.

15. Schell, D.J. \& Harwood, C. (1994). Milling of lignocellulosic biomass. Appl. Biochem. Biotechnol. 45(1), 159-168. DOI: 10.1007/BF02941795.

16. Gravalos, I., Kateris, D., Xyradakis, P., Gialamas, T., Loutridis, S., Augousti, A., Georgiades, A. \& Tsiropoulos, Z. (2010). Biomass residue pellets for heating purpose. In FORMEC 2010: Forest Engineering: Meeting the Needs of the Society and The Environment, Padova, Italy.

17. Zaldivar, J., Nielsen, J. \& Olsson, L. (2001). Fuel ethanol production from lignocellulose: a challenge for metabolic engineering and process integration. Appl. Microbiol. Biotechnol. 56(1-2), 17-26. DOI: 10.1007/s002530100624.

18. Jenkins, B.M., Baxter, L.L., Miles, T.R.J. \& Miles, T.R. (1998). Combustion properties of biomass Fuel Process. Technol. 54(1-3), 17-46. DOI: 10.1016/S0378-3820(97)00059-3. 